\title{
Estimation of Aboveground Carbon Stocks in Selected Homegardens in Five Agro Ecological Regions of the Low Country Intermediate Zone of Sri Lanka
}

\author{
Senevirathne N.A.U.S. ${ }^{{ }^{*}}$, Ranasinghe D.M.S.H.K. ${ }^{1}$ and Wahala W.M.P.S.B ${ }^{2}$ \\ ${ }^{I}$ Department of Forestry and Environmental Science, University of Sri Jayewardenepura, \\ Nugegoda, Sri Lanka \\ ${ }^{2}$ Department of Eco Business, Sabaragama University of Sri Lanka, Belihuloya, Sri Lanka \\ *udarasampath31@gmail.com
}

\begin{abstract}
Global warming is the most widespread problem of the new millennium. Carbon dioxide $\left(\mathrm{CO}_{2}\right)$ is the most important greenhouse gas released as a result of human activities. As a consequence, global average temperature is projected to increase by 1.4 to $5.8{ }^{0} \mathrm{C}$ over the period of 1990 to 2100. Forest based land use systems such as natural forests, forest plantations and agroforestry systems store carbon in their biomass leading to reduction of the atmospheric Carbon dioxide levels. Management of forests and agroforestry systems is identified as the most promising option to mitigate atmospheric Carbon dioxide $\left(\mathrm{CO}_{2}\right)$. The objective of the present study was to investigate the carbon storage of homegardens located in the dry intermediate zone of Sri Lanka.

Homegardens were selected based on the agro ecological regions and three homegardens each were taken for detailed studies in the 5 agro ecological regions (IL1), (IL2), (IL3), (IL1-L2), (IL1-L3) and the locations of the gardens were Kurunegala, Chilaw, Mahiyangana, Monergala, Wellawaya and Tangalle. In each garden transects were laid to capture the maximum diversity using the Point Centre Quarter Method (PCQM) and a sampling intensity of around 60\% was obtained from each garden. Dbh and height were measured in each tree. Non woody trees and woody trees having $<1 \mathrm{~cm}$ dbh were excluded. Allometric regression equation $\mathrm{AGB}=0.0509 \mathrm{x}$ q D2H [AGB - abovegroud biomass $(\mathrm{kg})$; D - dbh $(\mathrm{cm})$ and $\mathrm{H}$ (height $(\mathrm{m})$ ] was used to estiamte the aboveground biomass while $\mathrm{W}_{\mathrm{c}}=\mathrm{W} * 0.5\left(\mathrm{~W}_{\mathrm{c}}\right.$-carbon weight, $\mathrm{W}-$ above ground dry weight) was used to estimate the carbon content.

According to the results, 55 woody species were recorded from the homegardens. The aboveground carbon stock was highest in the gardens in Chilaw (345.88 t/ha) followed by gardens in Wellawaya (287.41 t/ha), gardens in Kurunegala (274.66 t/ha), gardens in Tangalle (229.57 t/ha), gardens in Mahiyangana (191.32 t/ha). The gardens in Moneragala recorded the lowest $9149.58 \mathrm{t} / \mathrm{ha}$ ).
\end{abstract}

Keywords: Homegardens, Climate change, Carbon storage, Intermediate zone 